\title{
REPRESENTASI GAMBAR PADA KARTU TAROT KE DALAM BATIK LUKIS
}

\author{
Yuni Sarah \\ Program Studi Penciptaan Kriya \\ Pascasarjana ISI Yogyakarta Institut Sei Indonesia Yogyakarta \\ e-mail : yunisarahisi@gmail.com \\ Diterima : 12 April 2020. Disetujui : 15 Mei 2020. Dipublikasikan : 10 Juni 2020 \\ terbuka di bawah lisensi CC BY 4.0 (https://creativecommons.org/licenses/by/4.0/)
}

\begin{abstract}
ABSTRAK
Kartu Tarot memiliki makna tersendiri yaitu mempunyai daya magis, namun masih dapat diterima akal. Rasa penasaran tentang diri sendiri dan apa yang akan terjadi nantinya yang dikemukakan ini juga dipandang penting. Sejatinya semenjak dahulu sampai sekarang pola yang mendasari kehidupan tetap sama namun berbeda cara dan bermacam-macam kondisi karena itulah tokoh-tokoh tersebut dapat berfungsi sebagai gambaran atau simbol dari kepribadian dan keadaan. Representasi yaitu proses sebuah objek tertangkap oleh indra seseorang, lalu masuk ke akal untuk diproses yang hasilnya adalah sebuah konsep atau ide yang dengan bahasa akan disampaikan atau diungkapkan kembali.Karya ini diawali dengan perenungan, mencari data, eksperimen yang kemudian menjadi bahan acuan dalam penciptaan ini. setelah itu dimulai dengan membuat sketsa rancangan, pemilihan bahan, hingga tahap perwujudan yang dilakukan dengan mengadaptasi teknik struckbrush atau sapuan kuas dari lukisan dan warna menggunakan teknik tutup celup hingga pelorotan.Hasil karya batik dengan memfokuskan pada visual karakter ini dimaksudkan untuk menampilkan proses dalam menginovasi teknik. Hasil karya yang didapatkan, mempunyai kesamaan karakter memberikan kesan karakter yang kuat dan menarik dalam setiap karya. Melihat dan meninjau dari hasil penciptaan tugas ini, dapat ditegaskan bahwa pengembangan teknik sangatlah penting. Penciptaan ini diharapkan dapat menjadi kontribusi didalam dunia Tekstil, untuk selalu mengembangkan teknik agar mendapatkan proses yang menyenangkan dan hasil yang menarik.
\end{abstract}

Kata kunci: Batik, Lukis, Representasi, kartu tarot, teknik struckbrush

\begin{abstract}
ABSTRAK
Tarot card has its own meaning, namely to have a magical power, but still acceptable. Curiosity about myself and what will happen later expressed also is viewed essential. In fact, since the first till now the underlying pattern of life remain the same but different ways and various conditions because that's what these figures can function as a picture or symbol of the personality and circumstances. Representation of a process object that is caught by one's senses, and then sign in to makes sense to the processed result is a concept or idea which language will be delivered or disclosed again.This paper begins with contemplation, searching for data, experiments which later became the material of reference in creation. After that begins with sketching the design, material selection, to the stage of manifestation made by adapting the techniques of struckbrush or brush strokes of the painting and the color of the lid using the technique of dipping to the dying process. Batik works by focusing on visual character is intended to show the process in menginovasi techniques. The work brings, have in common the characters give the impression of a powerful and compelling characters in each work. View and review the results of the creation of this task, it can be affirmed that the development of techniques is essential. Creation is expected to be a contribution in the world is textiles, to always develop the technique in order to get the process fun and interesting results.
\end{abstract}

Keyword : Batik, painting, representation, tarot cards, struckbrus

\section{PENDAHULUAN}

Sebagian orang menganggap bahwa mimpi adalah sebuah pertanda atau simbol. Pertanda untuk menemukan suatu jalan sehingga tak heran jika ada yang menanyakannya pada pembaca Kartu Tarot untuk mengetahui arti mimpi tersebut. Manusia terlahir ke muka bumi dengan tubuh yang terdiri atas berbagai lapisan kesadaran. Lapisan tubuh tersebut meliputi dua aspek yang saling berhubungan yaitu tubuh fisik dan lapisan energi. Sifat tubuh fisik dapat terindera oleh panca indera, tersentuh oleh panca indera manusia, sementara lapisan energi yang terdiri atas lapisan emosional, lapisan intelegensia dan lapisan kesadaran murni tidak mampu terjangkau oleh indera secara kasar. Kehadiran Kartu Tarot di kalangan anak muda mengakibatkan banyaknya illustarasi baru Kartu Tarot. Hal inilah yang menarik dan menjadi inspirasi dalam membuat karya. Dalam benak penulis Kartu Tarot memiliki makna tersendiri yaitu mempunyai daya 
magis, namun masih dapat diterima akal. Rasa penasaran tentang diri sendiri dan apa yang akan terjadi nantinya yang dikemukakan ini juga dipandang penting. Dengan mengetahui rasa penasaran melalui Kartu Tarot akan dengan mudah mengantisipasi hal-hal yang akan terjadi dan juga dapat dijadikan semangat.

Kartu Tarot adalah suatu sistem kartu bergambar yang umumnya terdiri dari 78 lembar kartu. Kartu Tarot biasanya digunakan untuk 'membaca' keadaan, situasi, dan jalur hidup seseorang. Asal kata Kartu Tarot sendiri mempunyai banyak versi ada yang mengatakan kata Kartu Tarot berasal dari bahasa Mesir kuno, ada yang mengatakan dari bahasa Arab, Tarekat. Masyarakat barat pada umumnya menerima asal usul kata tarot adalah berasal dari bahasa Italia, Tarrochi. Masyarakat Perancis menggunakan nama Tarot, dan masyarakat Jerman menyebut Tarock (Rimba et al.,2010:34-35).

Kartu Tarot adalah media yang berfungsi untuk menjembatani pernyataan alam bawah sadar kita. Namun pernyataan tersebut masih bersifat simbolik (dinyatakan dengan kartu), oleh karena banyaknya variabel bebas di alam maka dibutuhkan seorang pembaca Kartu Tarot untuk mengartikan simbol yang ditunjukkan kartu tersebut dan mencari benang merahnya dengan penanya, jadi yang menjawab apa atau siapa sebenarnya adalah alam bawah sadar dari penanya itu sendiri. Mungkin bisa diibaratkan bahwa alam bawah sadar penanya tersebut berbicara dalam bahasa Jerman, sementara penanya tidak mengerti bahasa Jerman maka dibutuhkan penerjemahnya, yaitu Kartu Tarot dan si pembaca Kartu Tarot tersebut. Jadi tidak benar anggapan orang bahwa Kartu Tarot berbau mistik, klenik, berhubungan dengan jin, kekuatan iblis dan lain-lain. (Hisyam A. F: 2010), Seorang pakar Tarot Psikologi, menjelaskan bahwa Kartu Tarot sangatlah logis sama halnya ketika mempelajari kartu Rorschacha yaitu alat psikologi proyektif berupa gambar bercak tinta. Dalam pembelajaran psikologi maka, seperti itulah Kartu Tarot diapresiasikan walau memang ada perbedaan cara mengaplikasikannya. Hal inipun berlaku pada alat tes psikologi proyektif lainnya. Dengan demikian pada dasarnya pemahaman terhadap Kartu Tarot dapat dikaji melalui konsep keilmuan atau bagian kecil dari psikologi, karena konsep Kartu Tarot mengandung simbol dari kehidupan yang telah terkonsep dari dahulu kala. Sejatinya semenjak dahulu sampai sekarang pola yang mendasari kehidupan tetap sama namun berbeda cara dan bermacam-macam kondisi karena itulah tokoh-tokoh tersebut dapat berfungsi sebagai gambaran atau simbol dari kepribadian dan keadaan.

Kamus Besar Bahasa Indonesia (KBBI), arti representasi yaitu perbuatan mewakili, keadaan diwakili, apa yang mewakili dan perwakilan. Representasi adalah proses sebuah objek tertangkap oleh indra seseorang, lalu masuk ke akal untuk diproses yang hasilnya adalah sebuah konsep atau ide yang dengan bahasa akan disampaikan atau diungkapkan kembali. (Dikutip dari http ://www.kompasiana. com/anggraini.m.e/representasi pada tanggal 28 Februari 2017 pukul 3:30 WIB). Setelah memahami gambar pada Kartu Tarot dari berbagai literatur Kartu Tarot dreaming way, penulis berusaha mencoba menuangkannya ke dalam karya seni batik lukis dengan teknik tulis dengan teknik pewarnaan tutup celup lorodan. Karya seni batik kali ini menggambarkan tokoh Kartu Tarot dengan berbagai kisahnya. Dari sisi visual dalam semua karya batik yang penulis ciptakan ini mengekspresikan proporsi tubuh yang digambarkan dengan penggayaan naif, dan berambut keriting sesuai kebutuhan.

Visual yang dihadirkan dalam penciptaan berupa gambaran dari simbol yang telah diterjemahkan dari Kartu Tarot itu sendiri dan dalam penciptaan ini, tidak semua yang ada dalam Kartu Tarot itu akan diwujudkan menjadi karya seni, tetapi akan dipilih beberapa kartu yang mengandung makna dan paling melekat pada pribadi penulis sebagai cerminan diri yang akan diwujudkan menjadi karya seni. Pada dasarnya konsep penggunaan secara umum Kartu Tarot sama, namun yang membedakan dari setiap satu set Kartu Tarot adalah desain sebagai tema yang mewakili unsur budaya setempat ditambah perkembangan Kartu Tarot lokal di Indonesia masih rendah maka hal ini menjadi peluang besar untuk menggunakan lokalitas sebagai sarana memperkaya ragam Kartu Tarot lokal. Umumnya penggambaran Kartu Tarot dalam karya seni selalu dibuat dengan bentuk grafis dan berbahan keras seperti kartu akan tetapi dalam karya ini sesuai dengan minat utama penulis, yaitu Kriya Tekstil.

Penciptaan karya ini dengan media kain menggunakan teknik batik tulis. Banyak hal yang mendorong untuk menciptakan karya batik tulis yang mengadaptasi teknik lukis, salah satunya adalah saat ini masyarakat sudah mulai meninggalkan akan seni batik terutama dengan teknik tradisional seperti pewarnaan tutup celup dan tidak sedikit dari masyakarat yang kurang memahami batik lukis

\section{Batik Lukis}

Menurut Tulus Warsito dalam buku karya Asti Musman dan Ambar B. Arini mengungkapkan setidaknya ada dua pengertian tentang batik. Pertama, batik merupakan teknik tutup-celup dalam pembentukan gambar kain, menggunakan lilin sebagai perintang dan zat warna bersuhu dingin sebagai bahan pewarna desain pada katun. Kedua, batik adalah sekumpulan desain yang sering digunakan dalam pembatikan pada pengertian pertama tadi, yang kemudian berkembang menjadi ciri khas desain tersendiri walupun desain tersebut tidak lagi dibuat di atas katun dan tidak lagi menggunakan lilin (Musman, 2011:3)

Dari penjelasan tersebut banyak bermunculan jenis lukisan yang bermedia batik saat ini karena banyak anggapan dari para seniman batik bahwa batik juga dapat menjadi sebuah media atau cara dalam berkarya membuat lukisan, maka terdapat buku yang menjelasan pemahaman tersebut yang di tulis oleh 
Syukur (2005: 37) bahwa pada dasarnya batik termasuk salah satu jenis lukis. Bentuk - bentuk yang dilukiskan di atas kain di sebut ragam hias, bahkan secara teknik pembuatan lukisan batik juga menggunakan teknik membatik hanya saja lebih modern. Beberapa perdebatan muncul perihal batik sebagai lukisan dan lukisan dengan teknik batik yang juga dapat dikatakan sebuah teknik pada pembuatan lukisan karena tekniknya memakai kuas yang selalu menjadi teknik melukis. Dari permasalahan tersebut penulis menemukan pencerahan dalam permasalahan tersebut yang ditulis oleh Hamzuri (1981: VI) pada bukunya yang menjelaskan bahwa batik ialah lukisan atau gambar pada mori yang dibuat dengan menggunakan alat bernama canting. Dari penjelasan tersebut sudah sangat jelas bahwasanya batik juga pada dasarnya adalah sebuah lukisan. Pencerahan dalam permasalahan ini juga lebih dilanjutkan dan diperkuat oleh Hamzuri (1981: VI) yang lalu menjelaskan bahwasanya didalam kalangan seniman pelukis banyak sekali yang melukis dengan pola motif batik dan lukisan tersebut disebut lukisan batik.

\section{Tinjauan Tentang Representasi}

Representasi biasanya dipahami sebagai gambaran sesuatu yang akurat atau realita yang terdistorsi. Reprepresentasi tidak hanya berati to present, to image, atau to depict. Kedua gambaran politisi hadir untuk merepresentasikan kepada kita. Kedua ide ini berdiri bersama untuk menjelaskan gagasan mengenai representasi. Representasi adalah sebuah cara memaknai apa yang diberikan pada benda yang digambarkan. Konsep lama mengenai representasi ini didasarkan pada premis bahwa ada sebuah gap representasi yang menjelaskan perbedaan antara makna yang diberikan oleh representsi dan arti benda yang sebenarnya digambarkan. hal ini terjadi antara representasi dan benda yang digambarkan. Namun berlawan dengan pemahan standar itu, Stuart Hall berargumentasi bahwa representasi harus dipahami dari peran aktif dan kreatif orang memaknai dunia. Hall menunjukkan bahwa sebuah imaji akan mempunyai makna yang berbeda dan tidak ada garansi bahwa imaji akan berfungsi atau berkerja sebagaimana mereka dikreasi atau dicipta. Hall menyebutkan representasi sebagai konstitutif. Representasi tidak hadir sampai setelah selesai direpresentasikan, representasi tidak terjadi setelah sebuah kejadian. Representasi adalah sebuah konstitutif dari sebuah kejadian. Represesntasi adalah bagian dari objek itu sendiri, ia adalah konstitutif darinya. (Dikutip dari Yolagani.wordpress.com pada tanggal 15 mei 2017 pukul 3:30 WIB).

\section{Tinjauan Tentang Tarot}

Kartu Tarot adalah suatu sistem kartu bergambar yang umumnya terdiri dari 78 lembar kartu. Kartu Tarot biasanya digunakan untuk 'membaca' keadaan, situasi, dan jalur hidup seseorang. Asal kata Tarot sendiri mempunyai banyak versi ada yang mengatakan kata Tarot berasal dari bahasa Mesir kuno, ada yang mengatakan dari bahasa Arab, Tarekat. Namun versi yang banyak diterima masyarakat barat adalah versi yang mengatakan kata Tarot berasal dari bahasa Italia, Tarrochi. Di perancis digunakan nama Tarot, dan di Jerman disebut Tarock (Rimba et al.,2010:34-35)

Hiyam A. F, (2010), seorang pakar Tarot Psikologi, menjelaskan bahwa Kartu Tarot sangatlah logis sama halnya ketika mempelajari Kartu Rorschacha yaitu alat psikologi proyektif berupa gambar bercak tinta. Dalam pembelajaran psikologi maka, seperti itulah Kartu Tarot diapresiasikan walau memang ada perbedaan cara mengaplikasikannya, hal inipun berlaku pada alat tes psikologi proyektif lainnya. Dengan demikian pada dasarnya pemahaman terhadap Kartu tarot dapat dikaji melalui konsep keilmuan atau bagian kecil dari psikologi, karena konsep Tarot mengandung simbol dari kehidupan yang telah terkonsep dari dulu kala. Dengan kata lain sejatinya semenjak dahulu sampai sekarang pola yang mendasari kehidupan tetap sama namun berbeda cara dan bermacam-macam kondisi karena itulah tokoh-tokoh tersebut dapat berfungsi sebagai gambaran atau simbol dari kepribadian dan keadaan.

\section{METODE PENELITIAN}

\section{Metode Pendekatan}

Metode pendekatan yang digunakan oleh penulis dalam pembuatan karya tugas akhir ini adalah metode estetik. Dalam pembuatan karya ini terdapat tiga unsur estetik yang mendasar, yaitu: keutuhan atau kebersatuan (unity), penonjolan atau penekanan (dominance), keseimbangan (balance). Metode ini merupakan suatu pendekatan yang menjelaskan keterkaitan penciptaan karya dengan aspek estetika mengacu pada beberapa pengertian dasar estetik, terutama estetika timur dalam karakteristik estetika yang lebih menekankan intuisi daripada akal, dihubungkan dengan penciptaan karya yang dilakukan (Sachari, 2002 :9-10). Pada tingkatan pertama adalah melakukan pemgamatan terhadap kualitas. Pendekatan yang menginterpretasikan bentuk visual ke dalam sistem tanda dan simbol. Keberadaan semiotika tidak dapat dilepaskan dalam proses penciptaan karya seni. Semiotika dipergunakan untuk lebih memperjelas maksud yang ingin disampaikan seniman kepada penikmatnya. Semiotika merujuk kepada ilmu atau metode analisis untuk mengkaji tanda, yaitu perangkat untuk mencari jalan di tengah-tengah manusia dan bersama-sama manusia lainnya (Sobur, 2009:15)

\section{Metode Penciptaan}

Metode penciptaan adalah cara yang dipakai dalam pengumpulan data di lapangan maupun studi lainnya guna mendukung kelancaran proses penciptaan karya seni. Metode penciptaan menurut Gustami (2004 : 29-32 ) terdapat tiga tahapan yaitu tahap eksplorasi, tahap perangcangan, dan tahap perwujudan. 


\section{Eksplorasi}

Metode ini digunakan untuk menyelidiki data dari kartu strenght, queen of cups, page of pentacles, the high priestess, two of wands, the wheel of forrtune, the chariot, eight of swords yang sudah ada kemudian data gunakan untuk mencari bentuk baru. Berberapa langkah eksplorsi yang dilakukan yaitu:

a. Pengambaran objek dari berbagai interpretasi dalam beberapa jenis kartu Tarot, pengamatan dari berbagai cerita pembaca tarot dan gambar dari Kartu Tarot itu sendiri.

b. Penggalian landasan dari beberapa teori yang akan dipakai dan data acuan dari beberapa sumber yang menggambarkan visual Kartu Tarot.

2. Perancangan

Metode ini digunakan dalam penciptaan karya sebelum karya diwujudkan pada media kain untuk dibatik. Metode ini berupa sketsa-sketsa alternatif dalam kertas yang kemudian dipilih sketsa yang paling baik dan tepat lalu diterapkan dalam media perwujudan berupa kain. Beberapa langkah metode perancangan sebagai berikut: Penuangan ide penggambaran karakter dari beberapa Kartu Tarot ke dalam kertas sketsa lalu diperbesar sesuai ukuran kain yang di inginkan lalu memola sketsa yang telah diperbesar tersebut menjadi gambar di kain.

\section{Perwujudan}

Perwujudan karya dilakukan dengan tahapan yang runtun agar tidak terjadi keliaran ekspresi atau karya keluar dari tema sebelumnya, yaitu mulai dari pengumpulan data, analisis sketsa, pembuatan desain, persiapan alat dan bahan, proses pengerjaan atau perwujudan karya serta finishing. Perwujudan penciptaan karya batik lukis tutup celup ini dimulai dari penuangan sketsa ke dalam kain dengan cara meletakkan kain di atas kertas lalu menggambar sesuai pola gambar yang ada dalam kertas sket yang sudah diperbesar tersebut. Selesai penggambaran pola pada kain lalu kain dibatik dengan canting dan setelah selesai proses pencantingan maka mulai masuk pada tahap pewarnaan kain dengan pewarna batik dan dilakukan dengan beberapa kali pewarnaan dan pencantingan sehingga memunculkan gradasi warna. Proses perwujudan terakhir yaitu pelorodan lilin malam dengan menggunakan soda AS atau soda abu dan air panasDalam menjawab pertanyaan penelitian tersebut, maka penulis menggunakan metode kritik seni dengan beberapa unsur yaitu dekspripsi, analisis formal, interpretasi dan judgement. Diharap dengan metode ini penulis dapat menjawab beberapa pertanyaan penelitian yang dibuat diatas.

\section{HASIL DAN PEMBAHASAN}

\section{Data Acuan}

Data acuan adalah keterangan yang didapat sebagai bahan dalam pola penafsiran yang ditetapkan sebagai dasar kajian. Pemilihan data acuan sangat diperlukan dalam proses pembuatan karya seni agar karya yang diciptakan mampu menggambarkan pesan yang ingin disampaikan agar terlihat lebih menarik, unik dan tidak membosankan. Semua data yang diperoleh kemudian dikorelasikan sebagai acuan sesuai dengan tema. Adapun data acuan yang berhasil dikumpulkan adalah sebagai berikut:

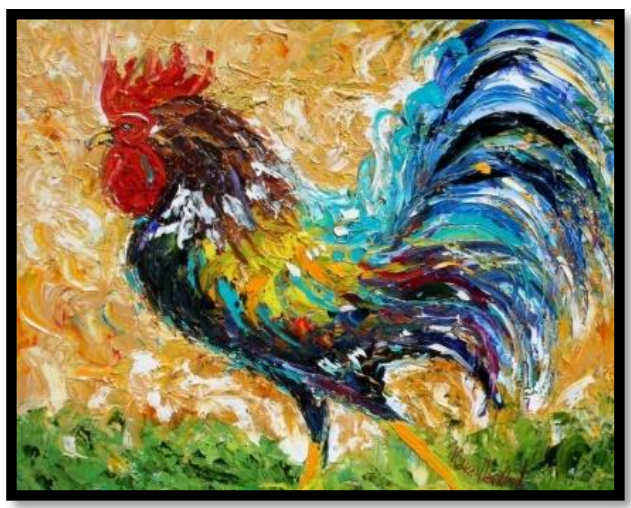

Gambar 1. Contoh lukis aliran impresionisme teknik Struckbrush

(Sumber: https://www.satujam.com/macam-macamlukisan/) Diakses pada 1 april 2017, pukul 11:09

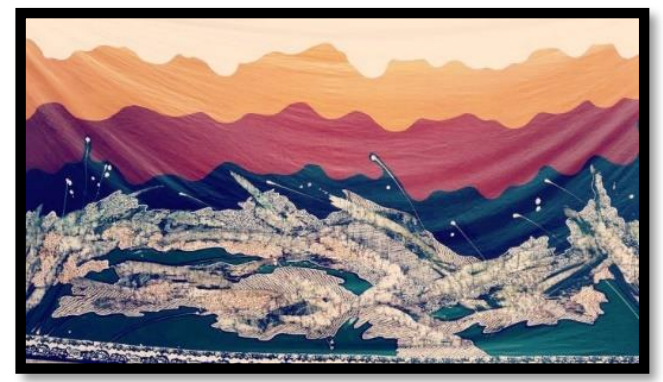

Gambar 2. Contoh batik lukis tutup celup bergradasi dengan motif abstrak karya batik Haryanto yang menjadi acuan kombinasi warna pada karya penulis

(Sumber:https://www.instagram.com/p/BLAAuglDniA/ Diaskes pada 28 februari 2016, pukul 19:50

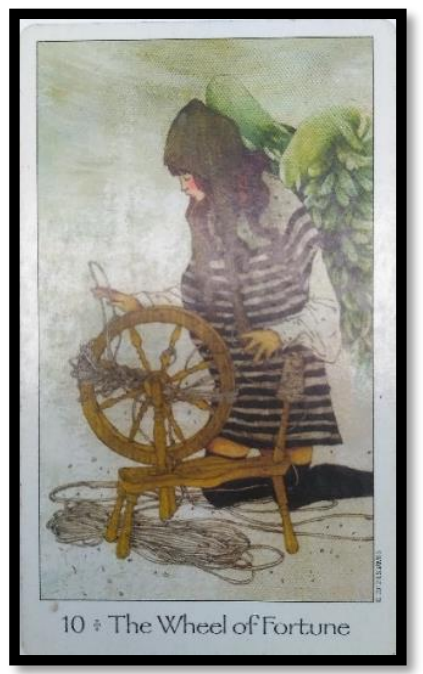

Gambar 3. Contoh gambar kartu tarot dreaming way yang berjudul The Wheel of Fortune 


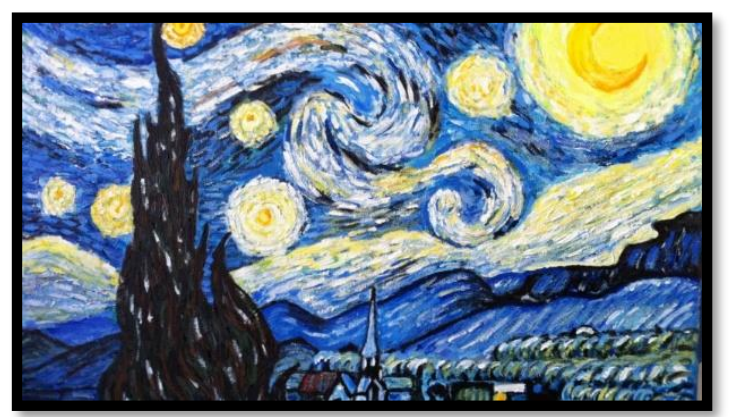

Gambar 5. Contoh Lukisan The Starry Night karya VanGogh menjadi referensi teknik Struckbrush (Sumber:http://blog.libero.it/georgeorwell1984/7461145.htm 1) Diakses pada 1 April 2017, pukul 15:01

\section{Rancangan Karya}

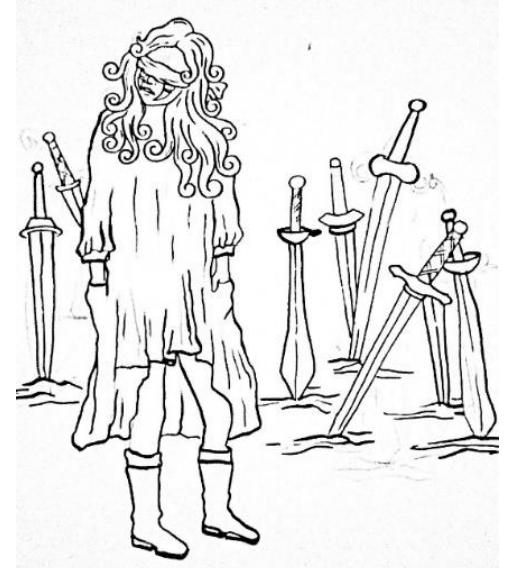

Gambar 6. Sketsa representasi dari kartu tarot dreaming way

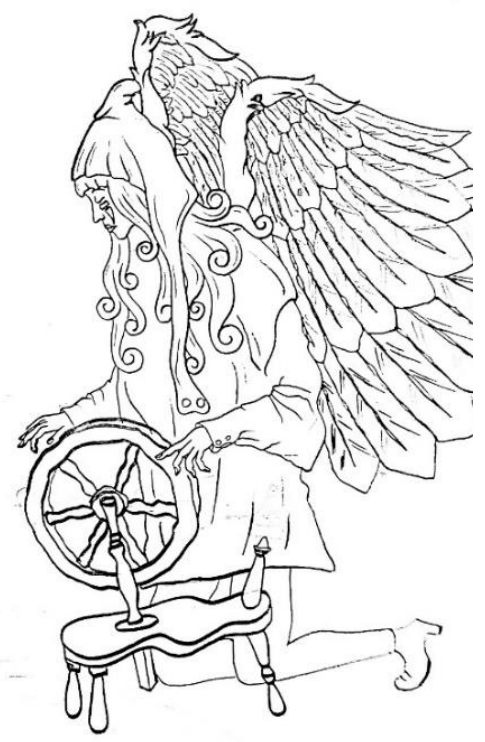

Gambar 7. Sketsa representasi dari kartutarot dreaming way

\section{Bahan dan Teknik}

Bahan dan alat yang digunakan yaitu seperti kain primissima, lilin malam, canting, kuas, kompor dan panci batik, pewarna yang digunakan pewarna napthol. Teknik yang digunakan menggunakan teknik tutup celup napthol serta mengadaptasi teknik struckbrush (impasto) dan pelorodan.

\section{Tahap Perwujudan}

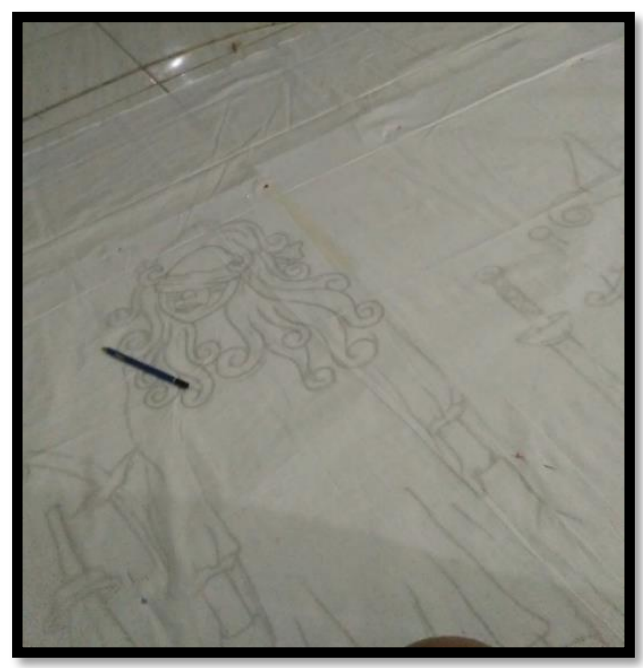

Gambar 8. Proses pemindahan pola pada kain (Fotografer: Eriko Fajar R, 2017)

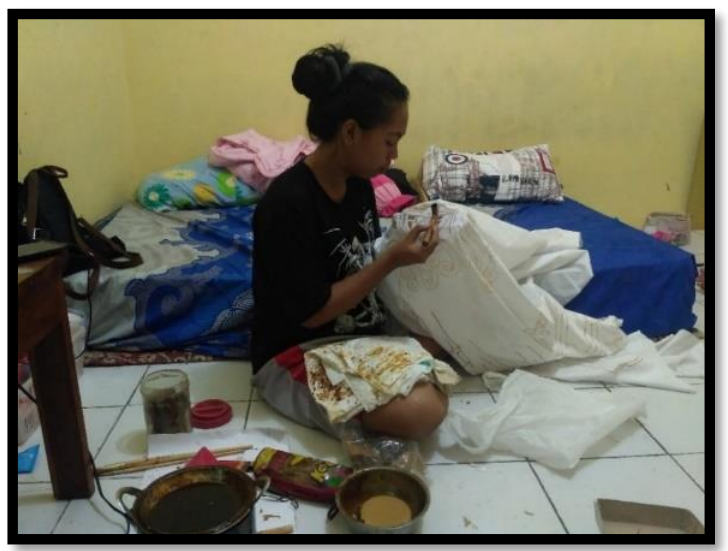

Gambar 9. Proses Pencantingan dan mengeblok pada kain sebelum pewarnaan

(Fotografer: Lifyatin A, 2017)

Menyanting, nembok atau mengeblok lilin malam pada kain dikerjakan pada saat kain akan diwarnai dan saat kain sudah diwarnai, tahap ini dikerjakan bersamaan dengan pencantingan isen. Proses nembok yang dilakukan sebelum pewarnaan dimulai guna menutupi kain saat masih berwarna putih agar saat setelah proses pelorodan selesai masih ada ruang untuk warna primer selanjutnya. 


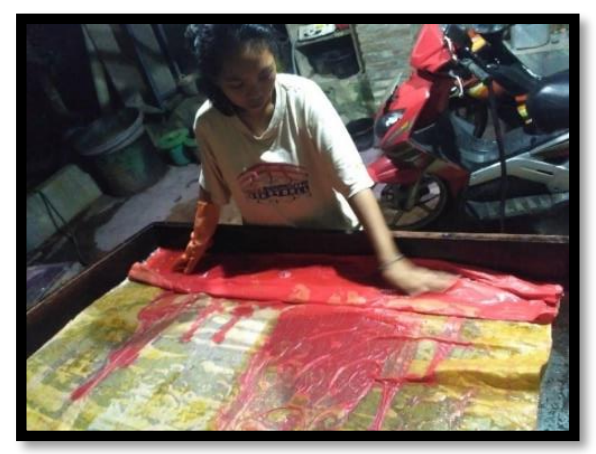

Gambar 10. Proses pemberian Napthol pada kain . (Fotografer: Eriko Fajar R, 2017)

Pada proses pewarnaan menggunakan Napthol dan garamnya ini penulis memakai beberapa tahapan maupun teknik khusus berdasarkan apa yang telah dipelajari dari sumber buku dan dipraktekan secara langsung sebelum proses pewarnaaan sesungguhnya berlangsung sehingga penulis mendapatkan racikan pribadi

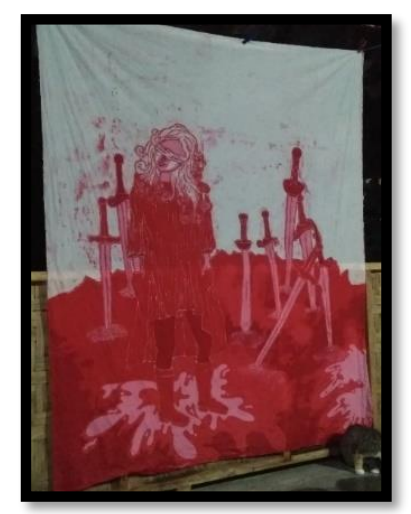

Gambar 11. Hasil lorodan pertama setelah beberapa kali tutup celup sampai mendapatkan warna yang gradasi diinginkaan

(Fotografer: Yuni Sarah, 2017)

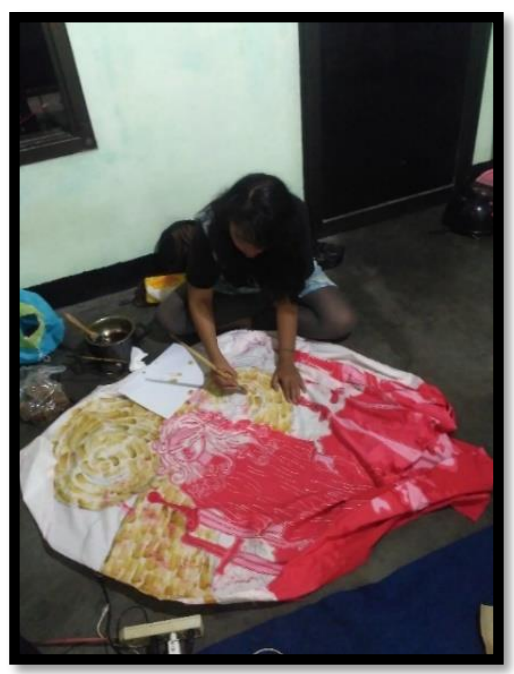

Gambar 12. Proses membuat struckbrush menggunakan malam dan kuas

(Fotografer: Eriko Fajar R, 2017
Teknik ini mengadaptasi dari seni lukis yaitu berupa sapuan kuas yang berulang ulang sehingga menghasilkan suatu kesan semu ketika diaplikasikan ke batik

Setelah melakukan teknik pewarnaan yang diualang-lang dan melakukan teknik impasto akan menghasilkan warna dan gradasi yang diinginkan, finishing yang dilakukan menggunakan figura dan spanram

\section{Hasil Penciptaan Karya}

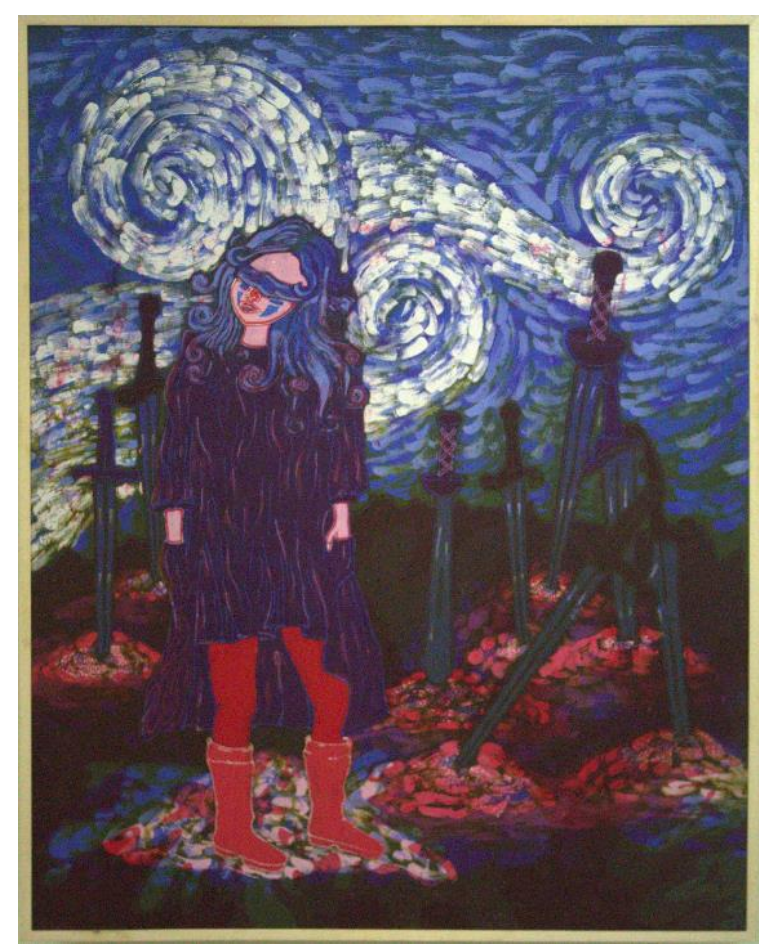

Gambar 13. Hasil representasi karya 1

(Fotografer: Yuni Sarah, 2017)

Judul : Acuh

Ukuran : $120 \mathrm{~cm}$ X $150 \mathrm{~cm}$

Bahan : primissima, Pewarna Naptol dan Indigosol Teknik : batik lukis, pewarnaan tutup celup, tutup struckbrush

Tahun : 2017

Diskripsi karya: Berangkat dari sebuah masalah dan terus bertambah membuat banyaknya perubahan diri entah menjadi semakin buruk atau sebaliknya. Semua tergantung bagaimana tanggapan terhadap masalah itu sendiri, belajar dari masa lalu dan berusaha tidak mengulanginya dimasa depan itu membuatmu menjadi lebih baik untuk melangkah ke step selanjutnya 


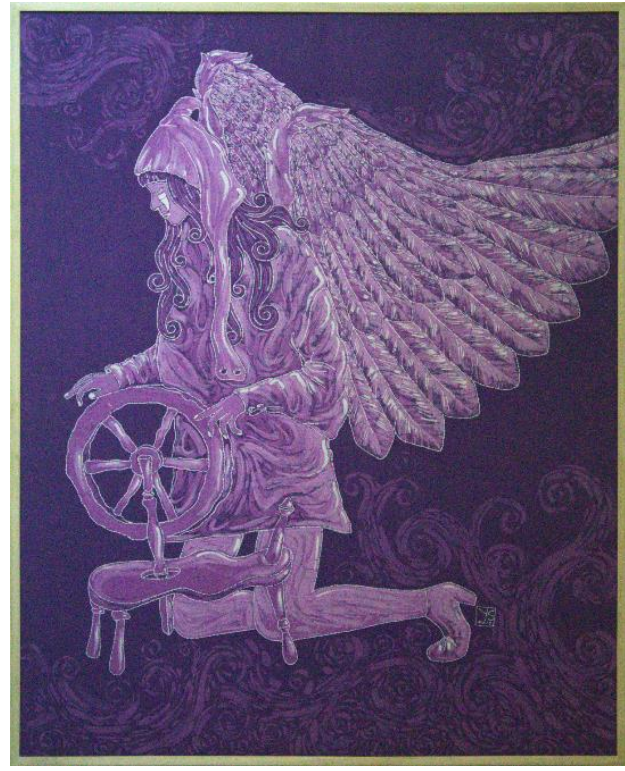

Gambar 14. Hasil representasi karya 2

(Fotografer: Yuni Sarah, 2017)

Judul : Peruntungan

Ukuran : $120 \mathrm{~cm}$ X $150 \mathrm{~cm}$

Bahan : primissima, Pewarna Indigosol

Teknik : batik lukis, pewarnaan tutup celup, tutup struckbrush

Tahun : 2017

Diskripsi karya: Karya ini meceritakan sebuah proses seseorang dalam mencapai sebuah kesuksesan, warna ungu memberi makna keprrbadian dengan tipe yang slalu optimis,menarik percaya diri dalam menghadapi segala hal lika-liku kehidupan. Warna unggu memberi makna kesan aktif dan kreatif dalam kehidupan dalam mencapai kesuksesan namun tidak semua tindakan atau perbuatan akan menghasilkan sebuah hasil yang istimewa, namun karya ini memberi makna bahwa kita harus tetap yakin bahwa sebuah proses tidak akan mendustai hasil.

\section{KESIMPULAN}

Karya seni diciptakan untuk mendapatkan kepuasan batin dan sebagai media untuk berekspresi. Karya-karya dalam Tugas Akhir ini merupakan media hasil dari pengolahan ide dalam konsep yang telah dipadukan dengan tema serta ekpresi yang penulis tuangkan. Berawal dari ketertarikan pada Kartu Tarot yang penuh misteri menjadikan penulis tertarik. Dalam karya ini juga merangkum setiap karakter yang ada pada diri penulis.

Secara keseluruhan karya yang penulis ciptakan pada Tugas Akhir ini memakai konsep Kartu Tarot dan mencoba menghadirkan kembali visualkan tokoh-tokoh dalam Kartu Tarot. Tahap perwujudan dilakukan dengan proses pencantingan dan kombinasi batik lukis teknik tutup Struckbrush. Proses pewarnaan memakai teknik tutup celup sehingga memunculkan kesan bergradasi dalam kontur warnanya. Penempatan kandungan semiotika dalam setiap karya yang penulis ciptakan diharapkan mampu untuk menjelaskan bagaimana konsep yang dipakai dalam karya.

Dalam pembuatan karya banyak terjadi hal yang tidak terduga karena menggunakan teknik tutup celup warna yang dihasilkan juga seperti menbaknebak, sebanyak empat karya diulang dari awal karna warna tidak sesuai ekspektasi dan hambatannya di penutupan warna karna harus mengulang-ulang menutup malam dari depan belakang depan agar tidak bocor ketika melakukan pewarnaan berikutnya.

Karya yang telah jadi dirasa memuaskan karena terbantu oleh dispalay yang mengasikkan teknik struckbrush nya juga dirasa sudah mewakili apa yang ingin ditunjukkan kepada masyarakat.

\section{DAFTAR PUSTAKA}

Ernawati, E. (2020). Psikologis Dalam Seni: Katarsis Sebagai Representasi Dalam Karya Seni Rupa. DESKOVI: Art and Design Journal, 2(2), 105-112..

Gustami, SP., "proses penciptaan seni kriya: Untaian Metodologis", Program Pascasarjana S2

Penciptaan dan Pengkaian Seni ISI Yogyakarta,2004

Hamzuri. (1981), Batik Klasik, Penerbit Djambatan, Jakarta.

Hisyam, A Fachri , (2010), Tarot Psikologi, Gagas Media, Jakarta.

Musman, Asti \& Ambar B. Arini, (2011), Batik: Wawasan Adiluhung Nusantara, Penerbit GMedia, Yogyakarta.

Rimba, Leonardo \& Audifax, (2010), Psikologi Tarot, Interprebook, Yogyakarta.

Sachari, Agus, (2005), Pengantar Metodologi Penelitian Budaya Rupa: Desain, Arsitektur, Seni Rupa dan Kriya, Erlangga.

Sobur, Alex, (2009), Semiotika Komunikasi, Remaja Rosdakarya, Bandung.

Syukur, Abdul, (2005), Ensiklopedia Umum Untuk Pelajar, Ichtiar Baru Van Hoeve, Jakarta. 
Yuni Sarah / DESKOVI : Art and Design Journal, Vol. 3, No.1, Juni 2020, 35-42

(Halaman ini sengaja dikosongkan) 